\title{
Pedobacter oryzae sp. nov., isolated from rice paddy soil
}

\author{
Yeji Jeon, ${ }^{1}$ Jeong Myeong Kim, ${ }^{2}$ Jin Ho Park, ${ }^{1}$ Se Hee Lee, ${ }^{2}$ \\ Chi-Nam Seong, ${ }^{3}$ Sang-Suk Lee ${ }^{4}$ and Che Ok Jeon ${ }^{2}$
}

Correspondence

Che Ok Jeon

cojeon@cau.ac.kr

\author{
${ }^{1}$ Environmental Biotechnology National Core Research Center, Gyeongsang National University, \\ Jinju 660-701, Republic of Korea \\ ${ }^{2}$ Department of Life Science, Chung-Ang University, Seoul 156-756, Republic of Korea \\ ${ }^{3}$ Department of Biology, Sunchon National University, Sunchon 540-742, Republic of Korea \\ ${ }^{4}$ Department of Animal Science \& Technology, Sunchon National University, Sunchon 540-742, \\ Republic of Korea
}

\begin{abstract}
A Gram-stain-negative, strictly aerobic bacterium, designated strain $N 7^{\top}$, was isolated from a rice paddy in South Korea. Cells of strain $N 7^{\top}$ were non-motile, non-spore-forming rods. Growth was observed at $15-35{ }^{\circ} \mathrm{C}$ (optimum of $25-30{ }^{\circ} \mathrm{C}$ ) and between $\mathrm{pH} 6.0$ and 8.0 (optimum of $\mathrm{pH}$ 6.5-7.5). The predominant isoprenoid quinone was menaquinone-7. The major cellular fatty acids of strain $N 7^{\top}$ were summed feature 3 (comprising $\mathrm{C}_{16: 1} \omega 7 \mathrm{c}$ and/or iso- $\mathrm{C}_{15: 0} 2-\mathrm{OH}$ ), iso$\mathrm{C}_{15: 0}$, anteiso- $\mathrm{C}_{15: 0}, \mathrm{C}_{15: 0}$ and iso- $\mathrm{C}_{16: 0}$. The $\mathrm{G}+\mathrm{C}$ content of the genomic DNA was $37.7 \mathrm{~mol} \%$. Comparative 16S rRNA gene sequence analyses showed that strain $\mathrm{N}^{\top}$ formed a distinct phyletic line within the genus Pedobacter. Phylogenetic distances from strains of other Pedobacter species with validly published names were greater than $5.0 \%$ (i.e. $<95.0 \% 16$ S rRNA gene sequence similarities). On the basis of phenotypic and molecular data, it is clear that strain N7 ${ }^{\top}$ represents a novel species within the genus Pedobacter, for which the name Pedobacter oryzae sp. nov. is proposed. The type strain is $N 7^{\top}$ (=KACC $12821^{\top}=\mathrm{DSM}$ $\left.19973^{\top}\right)$.
\end{abstract}

Since the genus Pedobacter, which belongs to the family Sphingobacteriaceae of the phylum Bacteroidetes, was first proposed by Steyn et al. (1998) to reclassify two Sphingobacterium species and to accommodate two novel species, a large number of Pedobacter species have been isolated from various habitats such as soil (Ten et al., 2006; Yoon et al., 2007a, b, c, d), water (Gallego et al., 2006; Muurholm et al., 2007), a glacier (Shivaji et al., 2005), sludge (Vanparys et al., 2005) and the rhizosphere (Kwon et al., 2007). In this study, taxonomic characterization is reported of strain $\mathrm{N}^{\mathrm{T}}$, which was isolated from a rice paddy and is related phylogenetically to members of the genus Pedobacter.

Strain $\mathrm{N}^{\mathrm{T}}$ was isolated from rice paddy soil associated with the roots of Oryzae sativa in Jinju $\left(35^{\circ} 19^{\prime} \mathrm{N} 128^{\circ} 09^{\prime}\right.$ E), South Korea. Rice roots were sampled in September 2006, soil debris was removed from the roots by washing with sterile saline $(0.9 \%, \mathrm{w} / \mathrm{v})$ and the suspension was

\footnotetext{
The GenBank/EMBL/DDBJ accession number for the 16S rRNA gene sequence of strain $\mathrm{N}^{\top}{ }^{\top}$ is EU109726.

A transmission electron micrograph of a cell of strain $N 7^{\top}$ is available as supplementary material with the online version of this paper.
}

serially diluted using $0.9 \%(\mathrm{w} / \mathrm{v})$ saline. The different dilutions were spread on R2A agar (Difco) and incubated at $25{ }^{\circ} \mathrm{C}$ for 5 days. Subcultivation was done routinely on R2A agar aerobically at $30{ }^{\circ} \mathrm{C}$ for 3 days, except where indicated otherwise, and the bacterial isolate was maintained as a glycerol stock at $-80{ }^{\circ} \mathrm{C}$.

Amplification and sequencing of the 16S rRNA gene of strain $\mathrm{N}^{\mathrm{T}}$ was carried out as described by Kim et al. (2008). Briefly, a single colony of strain $N 7^{\mathrm{T}}$ grown on $\mathrm{R} 2 \mathrm{~A}$ agar was resuspended in $100 \mu \mathrm{l}$ of $5 \%$ (w/v) Chelex-100 solution (Bio-Rad) and boiled for $10 \mathrm{~min}$ to prepare crude genomic DNA lysates. PCR amplification of 16S rRNA genes from the crude lysates was performed using the universal primers F1 (5'-AGAGTTTGATCMTGGCTCAG$\left.3^{\prime}\right)$ and R13 (5'-TACGGYTACCTTGTTACGACTT-3') as described previously (Lu et al., 2006). The resulting 16S rRNA gene sequence (1486 nt) was compared with available 16S rRNA gene sequences from GenBank using the BLAST program (http://www.ncbi.nlm.nih.gov/BLAST/) to determine an approximate phylogenetic affiliation and aligned with sequences of closely related members of the genus Pedobacter by using CLUSTAL W (Thompson et al., 1994). Phylogenetic trees were constructed by using three 
different algorithms, neighbour-joining, maximum-likelihood and maximum-parsimony, available in PHYLIP version 3.6 (Felsenstein, 2002). Resulting tree topologies were evaluated by bootstrap analysis based on 1000 resamplings. Sequence similarity values between the novel strain and other related bacteria were computed using the 'homology search' program in the EzTaxon server (http:// 147.47.212.35:8080/; Chun et al., 2007). Phylogenetic analysis based on $16 \mathrm{~S}$ rRNA gene sequences indicated that strain $\mathrm{N}^{\mathrm{T}}$ was most closely related to members of the genus Pedobacter within the family Sphingobacteriaceae, forming a distinct monophyletic lineage within this genus with a bootstrap value of $63 \%$ (Fig. 1). The overall topologies of the maximum-likelihood and maximumparsimony trees were essentially the same as that of the neighbour-joining tree (not shown). Comparative $16 \mathrm{~S}$ rRNA gene sequence analyses showed that strain $\mathrm{N}^{\mathrm{T}}$ was most closely related to Pedobacter steynii WB $2.3-45^{\mathrm{T}}$, Pedobacter ginsengisoli Gsoil $104^{\mathrm{T}}$, Pedobacter caeni DSM $16990^{\mathrm{T}}$ and Pedobacter africanus DSM $12126^{\mathrm{T}}$, with respective 16S rRNA gene sequence similarities of 95.0, 94.9, 94.6 and $94.2 \%$. These values are well below the threshold generally accepted for species delineation (Stackebrandt et al., 2002).

Growth was tested on laboratory-prepared Luria-Bertani (LB) agar and on R2A (Difco), tryptic soy (TSA; Difco) and nutrient (NA; Difco) agars at $30^{\circ} \mathrm{C}$.

Growth of strain $\mathrm{N}^{\mathrm{T}}$ at different temperatures and $\mathrm{pH}$ was examined by growing the isolate on R2A agar at $5-35{ }^{\circ} \mathrm{C}$ (at $5{ }^{\circ} \mathrm{C}$ intervals) and in $\mathrm{R} 2 \mathrm{~A}$ broth adjusted to $\mathrm{pH} 5.0$
10.0 (at $0.5 \mathrm{pH}$ unit intervals). Media with different $\mathrm{pH}$ values were prepared using appropriate biological buffers; $\mathrm{Na}_{2} \mathrm{HPO}_{4} / \mathrm{NaH}_{2} \mathrm{PO}_{4}$ and $\mathrm{Na}_{2} \mathrm{CO}_{3} / \mathrm{NaHCO}_{3}$ buffers were used below $\mathrm{pH} 8.0$ and for $\mathrm{pH} 8.0-10.0$, respectively (Gomori, 1955). Gram staining was performed using the bioMérieux Gram Stain kit according to the instructions of the manufacturer. Cell morphology and the presence of flagella were studied using phase-contrast microscopy and transmission electron microscopy (JEM-1010; JEOL) with 2-day-old cells grown on R2A agar as described previously (Bernardet et al., 2002; Jeon et al., 2004). Gliding motility was observed by direct microscopic examination of the edge of colonies grown on R2A agar with $1 \%(\mathrm{w} / \mathrm{v})$ agar. Salt tolerance was tested on R2A agar supplemented with $0-3 \%(\mathrm{w} / \mathrm{v}) \mathrm{NaCl}$ (at $0.5 \%$ intervals) for 5 days at $30{ }^{\circ} \mathrm{C}$. Oxidase and catalase activities and production of indole and $\mathrm{H}_{2} \mathrm{~S}$ were determined according to the methods of Smibert \& Krieg (1994). The production of flexirubin-type pigments and extracellular glycans was investigated using the $\mathrm{KOH}$ and Congo red tests, respectively, following the minimal standards for the description of new taxa in the family Flavobacteriaceae (Bernardet et al., 2002). Nitrate reduction was performed according to the method of Lányí (1987) and acid production from carbohydrates was tested as described by Leifson (1963). Biochemical features were characterized by using the API 20NE kit as recommended by the manufacturer (bioMérieux) except that the kit was incubated for 3 days at $30{ }^{\circ} \mathrm{C}$. Anaerobic growth was assessed under anaerobic (with 4-10\% $\mathrm{CO}_{2}$ ) conditions using the GasPak Plus system (BBL) at $30{ }^{\circ} \mathrm{C}$ for 15 days. The following tests were performed in parallel on strain

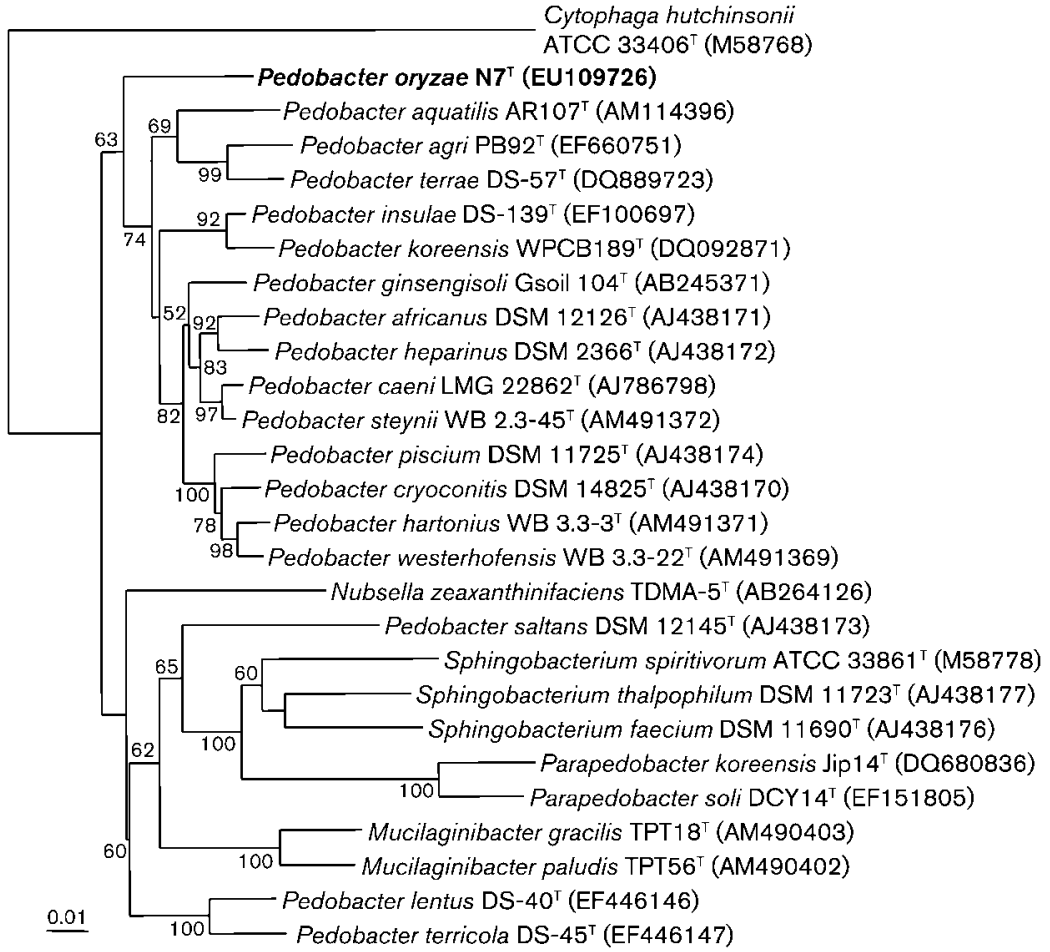

Fig. 1. Neighbour-joining tree based on $16 \mathrm{~S}$ rRNA gene sequences showing the phylogenetic relationships of strain $N 7^{\top}$ and related taxa. Bootstrap values (percentages of 1000 replicates) greater than $50 \%$ are shown. The sequence of Cytophaga hutchinsonii ATCC $33406^{\top}$ was used as an outgroup. Bar, 0.01 changes per nucleotide position. 
$\mathrm{N}^{\mathrm{T}}$ and on its closest relatives, $P$. steynii $\mathrm{WB} 2.3-45^{\mathrm{T}}, P$. ginsengisoli Gsoil $104^{\mathrm{T}}, \quad P$. caeni DSM $16990^{\mathrm{T}}$ and $P$. africanus DSM $12126^{\mathrm{T}}$. Antibiotic susceptibility tests were performed in duplicate using filter-paper discs $(8 \mathrm{~mm}$ diameter; Whatman) containing the following antibiotics: ampicillin $(10 \mu \mathrm{g})$, polymyxin $\mathrm{B}(100 \mathrm{U})$, streptomycin $(50 \mu \mathrm{g})$, penicillin $\mathrm{G}(10 \mathrm{IU})$, gentamicin $(30 \mu \mathrm{g})$, chloramphenicol $(100 \mu \mathrm{g})$, tetracycline $(30 \mu \mathrm{g})$, kanamycin $(30 \mu \mathrm{g})$, lincomycin $(15 \mu \mathrm{g})$, oleandomycin $(15 \mu \mathrm{g})$, neomycin $(30 \mu \mathrm{g})$, carbenicillin $(100 \mu \mathrm{g})$ and novobiocin $(50 \mu \mathrm{g})$. Hydrolysis of CM-cellulose, casein, gelatin, Tweens 80 and 20, aesculin, urea, tyrosine and starch was investigated on R2A agar after 7 days incubation at $30{ }^{\circ} \mathrm{C}$ according to previously described methods (Lányí, 1987; Smibert \& Krieg, 1994). Additional enzyme activities were characterized by using the API ZYM kit according to the instructions of the manufacturer (bioMérieux) except that the kit was incubated for 3 days at $30{ }^{\circ} \mathrm{C}$.

Bacterial cells were Gram-stain-negative, straight rods (see Supplementary Fig. S1 in IJSEM Online). The phenotypic features of strain $\mathrm{N}^{\mathrm{T}}$ are presented in Table 1 and in the species description. Some features are in accordance with the description of the genus Pedobacter, whereas others enable strain $\mathrm{N}^{\mathrm{T}}$ to be differentiated from closely related Pedobacter species (Table 1).

The whole-cell fatty acid compositions of strain $\mathrm{N}^{\mathrm{T}}$ and the four reference type strains $\left(P\right.$. steynii WB $2.3-45^{\mathrm{T}}, P$. ginsengisoli Gsoil $104^{\mathrm{T}}, P$. caeni DSM $16990^{\mathrm{T}}$ and $P$. africanus DSM $12126^{\mathrm{T}}$ ) were analysed according to the instructions of the Microbial Identification system (MIDI; Microbial ID) using cells grown on TSA at $30{ }^{\circ} \mathrm{C}$ for 3 days. Analysis of isoprenoid quinones was carried out using the methods described by Komagata \& Suzuki (1987). The DNA G+C content of strain $\mathrm{N}^{\mathrm{T}}$ was determined using an HPLC fitted with a reversed-phase column (GROM-SIL 100 ODS-2FE; GROM) according to the method of Tamaoka \& Komagata (1984). Strain $\mathrm{N}^{\mathrm{T}}$ contained menaquinone-7 as the major respiratory lipoquinone (at a peak area ratio of approximately $98 \%$ ). The cellular fatty acids ( $>9 \%$ of the total fatty acids) were

Table 1. Differential characteristics of strain $N 7^{\top}$ and the type strains of related Pedobacter species

Strains: 1, strain N7 ${ }^{\mathrm{T}}$ (data from this study); 2, P. steynii WB 2.3-45 ${ }^{\mathrm{T}}$ (unless indicated, data from Muurholm et al., 2007); 3 , P. caeni DSM 16990 ${ }^{\mathrm{T}}$ (Vanparys et al., 2005); 4, P. ginsengisoli Gsoil $104^{\mathrm{T}}$ (Ten et al., 2006; Yoon et al., 2007b); 5, P. africanus DSM $12126^{\mathrm{T}}$ (Steyn et al., 1998; Yoon et al., 2007b). All strains are positive for aerobic growth and for catalase, oxidase, alkaline phosphatase $\dagger$ and leucine arylamidase $\dagger$ activities. All strains are negative for Gram staining, sporulation, reduction of nitrate to nitrite, production of indole and $\mathrm{H}_{2} \mathrm{~S}$, hydrolysis of CM-cellulose $\dagger$ and urease $\dagger$, lipase (C14) $\dagger$ and $\alpha$-fucosidase $\dagger$ activities. All strains are resistant to ampicillin $\dagger$ and gentamicin $\dagger$. +, Positive; - , negative; w, weakly positive; NA, data not available.

\begin{tabular}{|c|c|c|c|c|c|}
\hline Characteristic & 1 & 2 & 3 & 4 & 5 \\
\hline Source of isolation & Soil & Water & Nitrifying inoculum & Soil & Soil, sludge \\
\hline Colony colour ${ }^{\star}$ & $\mathrm{P}$ & IW/PW & $\mathrm{CW} / \mathrm{Y}$ & WH & Y \\
\hline Maximum growth temperature $\left({ }^{\circ} \mathrm{C}\right)$ & 35 & 30 & 37 & 30 & 37 \\
\hline \multicolumn{6}{|l|}{ Hydrolysis of: $\dagger$} \\
\hline Tyrosine & - & - & - & + & - \\
\hline Starch & - & + & + & - & + \\
\hline Casein & - & + & - & - & - \\
\hline Gelatin & - & + & - & + & $\mathrm{w}$ \\
\hline Tween 20 & - & + & - & - & + \\
\hline Tween 80 & - & + & + & - & + \\
\hline Aesculin & + & + & + & - & + \\
\hline \multicolumn{6}{|l|}{ Enzyme activities (API ZYM): $\dagger$} \\
\hline Esterase (C4) & + & + & - & + & - \\
\hline Valine arylamidase & + & + & - & + & - \\
\hline Trypsin & $\mathrm{w}$ & + & - & - & - \\
\hline$\alpha$-Chymotrypsin & $\mathrm{w}$ & $\mathrm{w}$ & - & - & - \\
\hline$\beta$-Glucosidase & + & + & - & - & - \\
\hline$N$-Acetyl- $\beta$-glucosaminidase & - & + & - & + & + \\
\hline \multicolumn{6}{|l|}{ Susceptibility to: $\dagger$} \\
\hline Tetracycline & + & + & + & + & - \\
\hline Chloramphenicol & - & + & - & + & $\mathrm{w}$ \\
\hline DNA G $+C$ content $(\mathrm{mol} \%)$ & 37.7 & $\mathrm{NA}$ & 42.7 & 43.6 & $43.7-44.2$ \\
\hline
\end{tabular}

${ }^{*} \mathrm{CW}$, Creamish white; IW, ivory white; $\mathrm{P}$, pink; PW, pearl white; $\mathrm{WH}$, white; $\mathrm{Y}$, yellow.

$\dagger$ Results from this study. 
summed feature 3 (comprising $\mathrm{C}_{16: 1} \omega 7 \mathrm{c}$ and/or iso- $\mathrm{C}_{15: 0}$ 2-OH; $10.8 \%)$, iso- $\mathrm{C}_{15: 0}(10.7 \%)$, anteiso- $\mathrm{C}_{15: 0}(10.1 \%)$, $\mathrm{C}_{15: 0}(9.5 \%)$ and iso- $\mathrm{C}_{16: 0}(9.5 \%)$. Although the overall fatty acid profile of strain $\mathrm{N}^{\mathrm{T}}$ was similar to those of phylogenetically related species (Table 2), significant differences in the respective proportions of several components clearly distinguished strain $\mathrm{N}^{\mathrm{T}}$ (Vanparys et al., 2005; Ten et al., 2006). The G $+C$ content of the genomic DNA of strain $\mathrm{N}^{\mathrm{T}}$ was $37.7 \mathrm{~mol} \%$. The fatty acid composition and major lipoquinone of strain $\mathrm{N}^{\mathrm{T}}$ were in accordance with those of members of the genus Pedobacter (Steyn et al., 1998; Gallego et al., 2006; Ten et al., 2006), whereas the DNA G $+\mathrm{C}$ content of strain $\mathrm{N}^{\mathrm{T}}$ enabled it to be differentiated from related Pedobacter species (Table 1). Therefore, the data obtained in this polyphasic study support the description of strain $N 7^{\mathrm{T}}$ as representative of a

Table 2. Cellular fatty acid compositions (\%) of strain $N 7^{\top}$ and type strains of related Pedobacter species grown on TSA

Strains: 1 , strain $\mathrm{N}^{\mathrm{T}}$; 2, P. steynii WB $2.3-45^{\mathrm{T}}$; 3, P. caeni DSM $16990^{\mathrm{T}}$; 4, P. ginsengisoli Gsoil $104^{\mathrm{T}} ; 5$, P. africanus DSM $12126^{\mathrm{T}}$. All data are from this study. Fatty acids amounting to less than $1.0 \%$ in all strains are not shown. tr, Trace amount $(<1 \%)$; - not detected; ECL, equivalent chain-length.

\begin{tabular}{|c|c|c|c|c|c|}
\hline Fatty acid & 1 & 2 & 3 & 4 & 5 \\
\hline $\mathrm{C}_{14: 0}$ & $\operatorname{tr}$ & 1.1 & 3.9 & 1.1 & 1.6 \\
\hline $\mathrm{C}_{15: 0}$ & 9.5 & $\operatorname{tr}$ & $\operatorname{tr}$ & $\operatorname{tr}$ & - \\
\hline $\mathrm{C}_{16: 0}$ & 2.8 & 8.6 & 5.5 & 8.6 & 2.8 \\
\hline $\mathrm{C}_{17: 0}$ cyclo & - & 1.6 & 7.3 & - & - \\
\hline $\mathrm{C}_{15: 0} 2-\mathrm{OH}$ & 1.1 & $\operatorname{tr}$ & $\operatorname{tr}$ & 1.5 & - \\
\hline $\mathrm{C}_{16: 0} 3-\mathrm{OH}$ & $\operatorname{tr}$ & 2.4 & 2.4 & 1.4 & - \\
\hline $\mathrm{C}_{17: 0} 2-\mathrm{OH}$ & 4.1 & $\operatorname{tr}$ & $\operatorname{tr}$ & 3.5 & - \\
\hline iso- $\mathrm{C}_{14: 0}$ & 1.4 & - & $\operatorname{tr}$ & - & - \\
\hline iso- $\mathrm{C}_{15: 0}$ & 10.7 & 20.4 & 18.6 & 20.7 & 40.5 \\
\hline iso- $\mathrm{C}_{16: 0}$ & 9.5 & - & $\operatorname{tr}$ & $\operatorname{tr}$ & - \\
\hline iso- $\mathrm{C}_{16: 1} \mathrm{H}$ & 5.1 & - & - & - & - \\
\hline iso- $\mathrm{C}_{15: 0} 3-\mathrm{OH}$ & 1.1 & 4.2 & 4.3 & 4.0 & 3.1 \\
\hline iso- $\mathrm{C}_{16: 0} 3-\mathrm{OH}$ & 7.2 & $\operatorname{tr}$ & $\operatorname{tr}$ & $\operatorname{tr}$ & - \\
\hline iso- $\mathrm{C}_{17: 0} 3-\mathrm{OH}$ & 5.9 & 10.5 & 9.1 & 10.9 & 12.6 \\
\hline anteiso- $\mathrm{C}_{11: 0}$ & $\operatorname{tr}$ & 1.2 & $\operatorname{tr}$ & - & - \\
\hline anteiso- $\mathrm{C}_{15: 0}$ & 10.1 & $\operatorname{tr}$ & $\operatorname{tr}$ & 1.8 & 1.3 \\
\hline $\mathrm{C}_{15: 1} \omega 6 c$ & 6.6 & - & $\operatorname{tr}$ & $\operatorname{tr}$ & - \\
\hline $\mathrm{C}_{16: 1} \omega 5 c$ & $\operatorname{tr}$ & 1.9 & 2.2 & 2.0 & - \\
\hline $\mathrm{C}_{17: 1} \omega 6 c$ & 1.5 & - & - & - & - \\
\hline $\mathrm{C}_{17: 1} \omega 8 c$ & 1.4 & - & - & - & - \\
\hline iso- $\mathrm{C}_{17: 1} \omega 9 c$ & 2.7 & 1.8 & 1.8 & 3.0 & 7.8 \\
\hline anteiso- $\mathrm{C}_{17: 1} \omega 9 c$ & 1.6 & - & - & 1.1 & - \\
\hline Summed feature $3^{\star}$ & 10.8 & 39.4 & 38.1 & 30.8 & 26.8 \\
\hline Summed feature $4^{*}$ & - & $\operatorname{tr}$ & $\operatorname{tr}$ & 2.2 & 1.7 \\
\hline ECL 13.565 & - & 1.1 & $\operatorname{tr}$ & 1.5 & 2.0 \\
\hline ECL 13.961 & - & - & 1.4 & - & - \\
\hline
\end{tabular}

* Summed features represent groups of two or three fatty acids that cannot be separated by GLC with the MIDI system. Summed feature 3 contains iso- $\mathrm{C}_{15: 0}$ 2-OH and/or $\mathrm{C}_{16: 1} \omega 7 c$. Summed feature 4 contains iso- $\mathrm{C}_{17: 1} \mathrm{I}$ and/or anteiso- $\mathrm{C}_{17: 1} \mathrm{~B}$. novel species of the genus Pedobacter, for which the name Pedobacter oryzae sp. nov. is proposed.

\section{Description of Pedobacter oryzae sp. nov.}

Pedobacter oryzae (o.ry'zae. L. fem. n. oryzae of rice, referring to the rice paddy fields where the type strain was isolated).

Cells are Gram-stain-negative, non-motile, non-sporeforming, straight rods, $0.5-0.7 \mu \mathrm{m}$ in diameter and 2.0 $3.0 \mu \mathrm{m}$ long when grown at $30{ }^{\circ} \mathrm{C}$ on $\mathrm{R} 2 \mathrm{~A}$ agar. Colonies on R2A agar are slightly raised, circular with regular edges and pink in colour. Growth occurs at $30{ }^{\circ} \mathrm{C}$ on R2A agar, LB, TSA and NA. Grows optimally on R2A agar without the addition of $\mathrm{NaCl}$; growth is severely inhibited on $\mathrm{R} 2 \mathrm{~A}$ agar containing more than $2 \%(\mathrm{w} / \mathrm{v}) \mathrm{NaCl}$. Growth on R2A agar occurs at $15-35{ }^{\circ} \mathrm{C}$ (optimum of $25-30{ }^{\circ} \mathrm{C}$ ) and at $\mathrm{pH}$ 6.0-8.0 (optimum of $\mathrm{pH}$ 6.5-7.5). Anaerobic growth is not observed after 15 days at $30{ }^{\circ} \mathrm{C}$ on $\mathrm{R} 2 \mathrm{~A}$ agar. Oxidase- and catalase-positive. Nitrate is not reduced to nitrite. Congo red is not absorbed by colonies and flexirubin-type pigments are not produced. Aesculin is hydrolysed. Casein, gelatin, tyrosine, Tweens 80 and 20, urea, starch and CM-cellulose are not hydrolysed. Indole and $\mathrm{H}_{2} \mathrm{~S}$ are not produced. Acid is produced from Dmannose, but not from D-fructose, D-galactose, raffinose, D-glucose, myo-inositol, lactose, melibiose, D-mannitol, Larabinose, arbutin or salicin. In the API ZYM kit, alkaline phosphatase, esterase (C4), esterase lipase (C8), leucine arylamidase, cystine arylamidase, valine arylamidase, $\alpha$ galactosidase, $\beta$-galactosidase, $\alpha$-glucosidase and $\beta$-glucosidase activities are present, but lipase $(\mathrm{C} 14), \beta$-glucuronidase, $N$-acetyl- $\beta$-glucosaminidase, $\alpha$-mannosidase and $\alpha$-fucosidase activities are absent. Weak enzymic activities are observed for trypsin, $\alpha$-chymotrypsin, acid phosphatase and naphthol-AS-BI-phosphohydrolase. Trisodium citrate is assimilated, but D-glucose, D-mannose, $\mathrm{N}$-acetylglucosamine, maltose, L-arabinose, D-mannitol, potassium gluconate, capric acid, adipic acid, malic acid and phenylacetic acid are not assimilated (API 20NE). Resistant to polymyxin B, gentamicin, kanamycin, oleandomycin, neomycin, ampicillin, streptomycin, penicillin G, lincomycin, chloramphenicol, carbenicillin and novobiocin, but sensitive to tetracycline. The major isoprenoid quinone is menaquinone-7. The major cellular fatty acids $(>9 \%$ of the total fatty acids) are summed feature 3 (comprising $\mathrm{C}_{16: 1} \omega 7 c$ and/or iso- $\left.\mathrm{C}_{15: 0} 2-\mathrm{OH}\right)$, iso- $\mathrm{C}_{15: 0}$, anteiso- $\mathrm{C}_{15: 0}$, $\mathrm{C}_{15: 0}$ and iso- $\mathrm{C}_{16: 0}$.

The type strain is $\mathrm{N7}^{\mathrm{T}}\left(=\mathrm{KACC} 12821^{\mathrm{T}}=\right.$ DSM $\left.19973^{\mathrm{T}}\right)$, isolated from rice paddy soil in South Korea. The DNA $\mathrm{G}+\mathrm{C}$ content of the type strain is $37.7 \mathrm{~mol} \%$ (HPLC).

\section{Acknowledgements}

These efforts were supported by grants from the BioGreen 21 Program (code no. 20070301034002), the Rural Development Administration and the MOST/KOSEF to the Environmental 
Biotechnology National Core Research Center (grant no. R15-2003012-02002-0), Republic of Korea.

\section{References}

Bernardet, J. F., Nakagawa, Y. \& Holmes, B. (2002). Proposed minimal standards for describing new taxa of the family Flavobacteriaceae and emended description of the family. Int J Syst Evol Microbiol 52, 1049-1070.

Chun, J., Lee, J.-H., Jung, Y., Kim, M., Kim, S., Kim, B. K. \& Lim, Y. W. (2007). EzTaxon: a web-based tool for the identification of prokaryotes based on 16 S ribosomal RNA gene sequences. Int J Syst Evol Microbiol 57, 2259-2261.

Felsenstein, J. (2002). PHYLIP (phylogeny inference package) version 3.6a. Distributed by the author. Department of Genome Sciences, University of Washington, Seattle, USA.

Gallego, V., García, M. T. \& Ventosa, A. (2006). Pedobacter aquatilis sp. nov., isolated from drinking water, and emended description of the genus Pedobacter. Int J Syst Evol Microbiol 56, 1853-1858.

Gomori, G. (1955). Preparation of buffers for use in enzyme studies. Methods Enzymol 1, 138-146.

Jeon, C. O., Park, W., Ghiorse, W. C. \& Madsen, E. L. (2004). Polaromonas naphthalenivorans sp. nov., a naphthalene-degrading bacterium from naphthalene-contaminated sediment. Int J Syst Evol Microbiol 54, 93-97.

Kim, J. M., Le, N. T., Chung, B. S., Park, J. H., Bae, J.-W., Madsen, E. L. \& Jeon, C. O. (2008). Influence of soil components on the biodegradation of benzene, toluene, ethylbenzene, and $o_{-}^{-}, m-$, and $p$-xylenes by the newly isolated bacterium Pseudoxanthomonas spadix BD-a59. Appl Environ Microbiol 74, 7313-7320.

Komagata, K. \& Suzuki, K. (1987). Lipid and cell-wall analysis in bacterial systematics. Methods Microbiol 19, 161-207.

Kwon, S.-W., Kim, B.-Y., Lee, K.-H., Jang, K.-Y., Seok, S.-J., Kwon, J.-S., Kim, W.-G. \& Weon, H.-Y. (2007). Pedobacter suwonensis sp. nov., isolated from the rhizosphere of Chinese cabbage (Brassica campestris). Int J Syst Evol Microbiol 57, 480-484.

Lányi, B. (1987). Classical and rapid identification methods for medically important bacteria. Methods Microbiol 19, 1-67.

Leifson, E. (1963). Determination of carbohydrate metabolism of marine bacteria. J Bacteriol 85, 1183-1184.

Lu, S., Park, M., Ro, H.-S., Lee, D. S., Park, W. \& Jeon, C. O. (2006). Analysis of microbial communities using culture-dependent and culture-independent approaches in an anaerobic/aerobic SBR reactor. J Microbiol 44, 155-161.

Muurholm, S., Cousin, S., Päuker, O., Brambilla, E. \& Stackebrandt, E. (2007). Pedobacter duraquae sp. nov., Pedobacter westerhofensis sp. nov.,
Pedobacter metabolipauper sp. nov., Pedobacter hartonius sp. nov. and Pedobacter steynii sp. nov., isolated from a hard-water rivulet. Int J Syst Evol Microbiol 57, 2221-2227.

Shivaji, S., Chaturvedi, P., Reddy, G. S. N. \& Suresh, K. (2005). Pedobacter himalayensis sp. nov., from the Hamta glacier located in the Himalayan mountain ranges of India. Int J Syst Evol Microbiol 55, 1083-1088.

Smibert, R. M. \& Krieg, N. R. (1994). Phenotypic characterization. In Methods for General and Molecular Bacteriology, pp. 607-654. Edited by P. Gerhardt, R. G. E. Murray, W. A. Wood \& N. R. Krieg. Washington DC: American Society for Microbiology.

Stackebrandt, E., Frederiksen, W., Garrity, G. M., Grimont, P. A. D., Kämpfer, P., Maiden, M. C. J., Nesme, X., Rosselló-Mora, R., Swings, J. \& other authors (2002). Report of the ad hoc committee for the reevaluation of the species definition in bacteriology. Int J Syst Evol Microbiol 52, 1043-1047.

Steyn, P. L., Segers, P., Vancanneyt, M., Sandra, P., Kersters, K. \& Joubert, J. J. (1998). Classification of heparinolytic bacteria into a new genus, Pedobacter, comprising four species: Pedobacter heparinus comb. nov., Pedobacter piscium comb. nov., Pedobacter africanus sp. nov. and Pedobacter saltans sp. nov. Proposal of the family Sphingobacteriaceae fam. nov. Int J Syst Bacteriol 48, 165-177.

Tamaoka, J. \& Komagata, K. (1984). Determination of DNA base composition by reversed-phase high-performance liquid chromatography. FEMS Microbiol Lett 25, 125-128.

Ten, L. N., Liu, Q.-M., Im, W.-T., Lee, M., Yang, D.-C. \& Lee, S.-T. (2006). Pedobacter ginsengisoli sp. nov., a novel DNase-producing bacterium isolated from soil of a ginseng field in South Korea. Int $J$ Syst Evol Microbiol 56, 2565-2570.

Thompson, J. D., Higgins, D. G. \& Gibson, T. J. (1994). CLUSTAL W: improving the sensitivity of progressive multiple sequence alignment through sequence weighting, position-specific gap penalties and weight matrix choice. Nucleic Acids Res 22, 4673-4680.

Vanparys, B., Heylen, K., Lebbe, L. \& De Vos, P. (2005). Pedobacter caeni sp. nov., a novel species isolated from a nitrifying inoculum. Int J Syst Evol Microbiol 55, 1315-1318.

Yoon, M.-H., Ten, L. N., Im, W.-T. \& Lee, S. T. (2007a). Pedobacter panaciterrae sp. nov., isolated from soil in South Korea. Int J Syst Evol Microbiol 57, 381-386.

Yoon, J.-H., Kang, S.-J., Oh, H. W. \& Oh, T.-K. (2007b). Pedobacter insulae sp. nov., isolated from soil. Int J Syst Evol Microbiol 57, 1999 2003.

Yoon, J.-H., Kang, S.-J., Park, S. \& Oh, T.-K. (2007c). Pedobacter lentus sp. nov. and Pedobacter terricola sp. nov., isolated from soil. Int J Syst Evol Microbiol 57, 2089-2095.

Yoon, J.-H., Kang, S.-J. \& Oh, T.-K. (2007d). Pedobacter terrae sp. nov., isolated from soil. Int J Syst Evol Microbiol 57, 2462-2466. 